\title{
PENEGAKAN HUKUM TERHADAP TINDAK PIDANA PENCEMARAN NAMA BAIK MELALUI PENGGUNAAN MEDIA SOSIAL DI KOTA SAMARINDA
}

\author{
Oleh : Endi Dwi Saputra ${ }^{1}$ dan Khairunnisah ${ }^{2}$
}

${ }^{1}$ Fakultas Hukum Universitas 17 Agustus 1945 Samarinda

${ }^{2}$ Dosen Fakultas Hukum Universitas 17 Agustus 1945 Samarinda

\begin{abstract}
The crime of defamation that often occurs in cyberspace is an act that attacks the good name. Offensive reputation is to convey words (words or a series of words / sentences) by accusing certain acts of being committed, and those aimed at the honor and good name of a person which can result in a person's sense of dignity, shame, or humiliation. Someone proven guilty of disseminating electronic information containing defamation as referred to in the elements of Article 27 paragraph (3) of Law number 19 of 2016 concerning amendments to Law number 11 of 2008 concerning Information and Electronic Transactions

This type of research used in this study is a type of empirical legal research, which is a legal research method that uses empirical facts taken from human behavior, with a qualitative approach.

The results of the research showed that the perpetrators' violation was a violation of the provisions of Article 27 paragraph (3) of Law number 19 of 2016 concerning amendments to Law number 11 of 2008 concerning Information and Electronic Transactions to be charged with Article 45 Paragraph (1) of the ITE Law which states: Every person who fulfills the elements referred to in Article 27 paragraph (1), paragraph (2), paragraph (3), or paragraph (4) shall be sentenced to a maximum imprisonment of 4 (six) years and / or a maximum fine of $R p$ 650,000 .000 .00 (Six Hundred Fifty Million Rupiah).
\end{abstract}

Keywords : Law Enforcement, Defamation, Social Media 


\section{PENDAHULUAN}

\section{A. Latar Belakang}

Abad ini memang merupakan abad yang selalu dikaitkan dengan media. Sebuah informasi yang kini sangat perlu dan mudah ditemukan oleh berbagai penjuru dunia mengakibatkan ia menjadi salah satu kebutuhan. Untuk memenuhi kebutuhan itu, media sosiallah yang banyak digunakan oleh masyarakat secara umum."1

Layanan-layanan yang ada pada media sosial pun beragam dan selalu mengalami peningkatan dari tahun ke tahun. Beberapa situs media sosial yang populer sekarang ini antara lain :Blog, facebook, twitter, instagram, whatsApp, Path, Line, dan masih banyak lagi yang lainnya."2 Media sosial sangat berpengaruh besar terhadap perkembangan dan perubahan masyarakat Indonesia, perubahannya pun beragam bisa membawa perubahan yang lebih baik seperti memberikan kontribusi bagi peningkatan kesejahteraan, kemajuan, dan peradaban , bahkan perubahan yang sangat buruk pun bisa terjadi di media sosial seperti penghihaan, ujaran kebencian, serta penyebaran informasi di media sosial yang dituju untuk menimbulkan rasa kebencian atau permusuhan antar individu atau kelompok masyarakat tertentu berdasarkan suku, agama, ras, dan antar golongan.

Media sosial dalam penggunaannya, digunakan oleh masyarakat sebagai media untuk mencari infomasi dan juga sebagai media untuk belajar, namun seiring perkembangannya penggunaan media sosial tidak hanya digunakan sebagai sarana untuk memperoleh informasi yang bermanfaat, tetapi juga digunakan sebagai media untuk melakukan kejahatan di dunia maya.

Kita harus sadari bahwa Indonesia merupakan salah satu negara pengguna internet dan media sosial terbesar di dunia sehingga penerapan etika / ketaatan hukum dalam masyarakat sangat dibutuhkan agar terhindar dari kejahatan di dunia maya.

Tindak pidana pencemaran nama baik yang kerap terjadi di dunia maya merupakan perbuatan yang menyerang nama baik. Penyerangan nama baik adalah menyampaikan ucapan (kata atau rangkaian perkataan/kalimat) dengan cara menuduhkan melakukan perbuatan tertentu, dan yang ditujukan pada kehormatan dan nama baik orang yang dapat mengakibatkan rasa harga diri atau martabat orang itu dicemarkan, dipermalukan atau direndahkan.

\footnotetext{
${ }^{1}$ Evra Willya. dkk, 2018, Senarai Penelitian Islam Kontemporer Tinjauan Multikultural, Deepublish, Yogyakarta, hal. 290

2 Suprawoto, 2018, Perkembangan Dan Praktik Di Indonesia, Prenadamedia Group, Jakarta , hal. 163.
} 
Seseorang yang terbukti dengan sengaja menyebarluaskan informasi elektronik yang bermuatan pencemaran nama baik seperti yang dimaksudkan dalam unsur Pasal 27 ayat (3) Undang Undang nomor 19 tahun 2016 tentang perubahan atas Undang Undang nomor 11 Tahun 2008 tentang Informasi dan Transaksi Elektronik akan dijerat dengan Pasal 45 Ayat (1) Undang-Undang Nomor 19 Tahun 2016 Perubahan Atas UndangUndang Nomor 11 Tahun 2008 yang menyebutkan: Setiap Orang yang memenuhi unsur sebagaimana dimaksud dalam Pasal 27 ayat (1), ayat (2), ayat (3), atau ayat (4) dipidana dengan pidana penjara paling lama 4 (enam) tahun dan/atau denda paling banyak Rp 750.000.000,00 (Tujuh Ratus Lima Puluh Juta Rupiah)

\section{B. Rumusan Masalah}

Dari hal-hal di atas maka peneliti ingin meneliti Bagaimanakah penegakan hukum terhadap tindak pidana pencemaran nama baik melalui penggunaan media sosial di Kota Samarinda serta faktor pemnghambat dalam penegakan hukum tersebut menjadi rumusan masalah sehingga menjadi fokus penelitian. Diharapkan hasil penelitian ini bermanfaat terhadap pengembangan ilmu hukum dan sebagai masukan bagi para penyelenggara negara dan yang terkait.

\section{KERANGKA DASAR TEORI}

\section{A. Pengertian Tindak Pidana}

Kata Tindak Pidana ditemukan dalam aturan pidana di Indonesia, antara lain ditemukan dalam Undang-Undang Nomor 19 Tahun 2002 tentang Hak Cipta, pakar lain yang menggunakan kata tindak pidana adalah Satochid Kartanegara, Menurutnya tindak pidana diartikan sebagai tindakan yang dilakukan oleh manusia untuk mana ia dapat dipidana.

a. Delik Berasal dari bahasa latin Delictum yang dapat dipakai untuk mengartikan strafbaar feit. Istilah ini dapat dijumpai dalam berbagai literatur, misalnya Utrecht meskipun beliau juga menggunakan istilah lain yaitu peristiwa pidana untuk mengartikan strafbaar feit yaitu peristiwa pidana.

b. Perbuatan Pidana Moeljatno, ia mengartikan Strafbaar feit dengan istilah perbuatan pidana, ia menuliskan bahwa perbuatan pidana merupakan suatu perbuatan yang dilarang oleh suatu aturan hukum, larangan tersebut disertai ancaman (sanksi) yang berupa pidana tertentu, bagi barang siapa melanggar aturan tersebut. 
Moelijatno tidak setuju dengan penggunaan istilah tindak pidana karena menurutnya kata "tindak" lebih pendek dari "perbuatan" sehingga hanya menunjukan suatu keadaan kongkrit saja."”

Setiap tindak pidana yang terdapat dalam Kitab Undang-Undang Hukum Pidana itu pada umumnya dapat dijabarkan ke dalam unsur-unsur yang pada dasarnya dapat dibagi menjadi dua macam unsur, yakni unsurunsur subjektif dan unsur-unsur objektif. Unsur-unsur subjektif itu adalah unsur-unsur yang melekat pada diri si pelaku atau yang berhubungan dengan diri si pelaku, termasuk ke dalamnya yaitu segala sesuatu yang terkandung di dalam hatinya.

Tindak pidana dikenal dengan istilah straafbar feit, akan tetapi dalam peraturan perundang-undangan Indonesia tidak ditemukan definisinya, begitupula dengan KUHP yang tidak menjelaskan secara rinci pengertian dari Straafbaar Feit tersebut. Strafbaar feit berasal dari bahasa belanda yang dibagi atas dua kata yaitu straafbaar yang berarti dapat dihukum dan feit memiliki pengertian sebagian dari suatu kenyataan, sehingga makna harfiah perkataan strafbaar feit adalah sebagian dari suatu kenyataan yang dapat dihukum, akan tetapi penjatuhan suatu hukuman tidak dapat dilakukan tanpa adanya seseorang yang melakukan perbuatan tersebut

\section{B. Teori Penegakan Hukum}

Penegakan hukum merupakan suatu usaha untuk mewujudkan ideide keadilan, kepastian hukum dan kemanfaatan sosial menjadi kenyataan. Jadi penegakan hukum pada hakikatnya adalah proses perwujudan ide-ide. Penegakan hukum adalah proses dilakukannya upaya tegaknya atau berfungsinya norma-norma hukum secara nyata sebagai pedoman pelaku dalam lalu lintas atau hubungan-hubungan hukum dalam kehidupan bermasyarakat dan bernegara. "Penegakan hukum merupakan usaha untuk mewujudkan ide-ide dan konsepkonsep hukum yang diharapakan rakyat menjadi kenyataan. Penegakan hukum merupakan suatu proses yang melibatkan banyak hal."4

Menurut Soerjono Soekanto, penegakan hukum adalah kegiatan menyerasikan hubungan nilai-nilai yang terjabarkan didalam kaidahkaidah/pandangan nilai yang mantap dan mengejewantah dan sikap tindak sebagai rangkaian penjabaran nilai tahap akhir untuk menciptakan, memelihara dan mempertahankan kedamaian pergaulan hidup. Penegakan hukum secara konkret adalah berlakunya hukum positif dalam praktik

\footnotetext{
${ }^{3}$ Leden Marpaung, 1991, Unsur- Unsur Perbuatan Yang Dapat Dihukum (Delik), Sinar Grafika, Jakarta, Hal. 3.

${ }^{4}$ Dellyana,Shant.2004, ,Konsep Penegakan Hukum, Liberty, Yogyakarta: hal 32
} 
sebagaimana seharusnya patut dipatuhi. Oleh karena itu, memberikan keadilan dalam suatu perkara berarti memutuskan hukum in concreto dalam mempertahankan dan menjamin di taatinya hukum materiil dengan menggunakan cara procedural yang ditetapkan oleh hukum formal. ${ }^{5}$

Penegakan hukum merupakan usaha untuk mewujudkan ide-ide dan konsepkonsep hukum yang diharapakan rakyat menjadi kenyataan. Penegakan hukum merupakan suatu proses yang melibatkan banyak hal. ${ }^{6}$

Joseph Goldstein membedakan penegakan hukum pidana menjadi 3 bagian yaitu:

1. Total enforcement, yakni ruang lingkup penegakan hukum pidana sebagaimana yang dirumuskan oleh hukum pidana substantif (subtantive law of crime). Penegakan hukum pidana secara total ini tidak mungkin dilakukan sebab para penegak hukum dibatasi secara ketat oleh hukum acara pidana yang antara lain mencakup aturanaturan penangkapan, penahanan, penggeledahan, penyitaan dan pemeriksaan pendahuluan. Disamping itu mungkin terjadi hukum pidana substantif sendiri memberikan batasan-batasan. Misalnya dibutuhkan aduan terlebih dahulu sebagai syarat penuntutan pada delik-delik aduan (klacht delicten). Ruang lingkup yang dibatasi ini disebut sebagai area of no enforcement.

2. Full enforcement, setelah ruang lingkup penegakan hukum pidana yang bersifat total tersebut dikurangi area of no enforcement dalam penegakan hukum ini para penegak hukum diharapkan penegakan hukum secara maksimal.

3. Actual enforcement, menurut Joseph Goldstein full enforcement ini dianggap not a realistic expectation, sebab adanya keterbatasanketerbatasan dalam bentuk waktu, personil, alat-alat investigasi, dana dan sebagainya, yang kesemuanya mengakibatkan keharusan dilakukannya discretion dan sisanya inilah yang disebut dengan actual enforcement.

\section{Faktor-Faktor Yang Mempengaruhi Penegakan Hukum}

Faktor faktor yang mempengaruhi penegakan hukum menurut Soerjono Soekanto adalah :

\section{Faktor Hukum}

Praktik penyelenggaraan hukum di lapangan ada kalanya terjadi pertentangan antara kepastian hukum dan keadilan, hal ini disebabkan oleh konsepsi keadilan merupakan suatu rumusan yang

\footnotetext{
${ }^{5}$ Ibid hlm 33

${ }^{6}$ Ibid hal 37
} 
bersifat abstrak, sedangkan kepastian hukum merupakan suatu prosedur yang telah ditentukan secara normatif.

Justru itu, suatu kebijakan atau tindakan yang tidak sepenuhnya berdasar hukum merupakan sesuatu yang dapat dibenarkan sepanjang kebijakan atau tindakan itu tidak bertentangan dengan hukum. Maka pada hakikatnya penyelenggaraan hukum bukan hanya mencakup law enforcement, namun juga peace maintenance, karena penyelenggaraan hukum sesungguhnya merupakan proses penyerasian antara nilai kaedah dan pola perilaku nyata yang bertujuan untuk mencapai kedamaian.

\section{Faktor Penegakan Hukum}

Fungsi hukum, mentalitas atau kepribadian petugas penegak hukum memainkan peranan penting, kalau peraturan sudah baik, tetapi kualitas petugas kurang baik, ada masalah. Oleh karena itu, salah satu kunci keberhasilan dalam penegakan hukum adalah mentalitas atau kepribadian penegak hukum.

\section{Faktor Sarana atau Fasilitas Pendukung}

Faktor sarana atau fasilitas pendukung mencakup perangkat lunak dan perangkat keras, salah satu contoh perangkat lunak adalah pendidikan. Pendidikan yang diterima oleh Polisi dewasa ini cenderung pada hal-hal yang praktis konvensional, sehingga dalam banyak hal polisi mengalami hambatan di dalam tujuannya, diantaranya adalah pengetahuan tentang kejahatan computer, dalam tindak pidana khusus yang selama ini masih diberikan wewenang kepada jaksa, hal tersebut karena secara teknis yuridis polisi dianggap belum mampu dan belum siap. Walaupun disadari pula bahwa tugas yang harus diemban oleh polisi begitu luas dan banyak.

\section{Faktor Masyarakat}

Penegak hukum berasal dari masyarakat dan bertujuan untuk mencapai kedamaian di dalam masyarakat. Setiap warga masyarakat atau kelompok sedikit banyaknya mempunyai kesadaran hukum, persoalan yang timbul adalah taraf kepatuhan hukum, yaitu kepatuhan hukum yang tinggi, sedang, atau kurang. Adanya derajat kepatuhan hukum masyarakat terhadap hukum, merupakan salah satu indikator berfungsinya hukum yang bersangkutan.

\section{Faktor Kebudayaan}

Berdasarkan konsep kebudayaan sehari-hari, orang begitu sering membicarakan soal kebudayaan. Kebudayaan menurut Soerjono Soekanto, mempunyai fungsi yang sangat besar bagi manusia dan masyarakat, yaitu mengatur agar manusia dapat mengerti bagaimana seharusnya bertindak, berbuat, dan menentukan sikapnya kalau mereka berhubungan dengan orang lain. Dengan demikian, kebudayaan adalah 
suatu garis pokok tentang perikelakuan yang menetapkan peraturan mengenai apa yang harus dilakukan, dan apa yang dilarang.

\section{Pengertian Pencemaran Nama Baik}

Nama baik adalah penilaian baik menurut anggapan umum tentang perilaku atau kepribadian seseorang dari sudut moralnya. Nama baik seseorang selalu dilihat dari sudut orang lain, yakni moral atau kepribadian yang baik, sehingga ukurannya ditentukan berdasarkan penilaian secara umum dalam suatu masyarakat tertentu di tempat mana perbuatan tersebut dilakukan dan konteks perbuatannya.

Pencemaran nama baik dikenal juga istilah penghinaan, yang pada dasarnya adalah menyerang nama baik dan kehormatan seseorang yang bukan dalam arti seksual sehingga orang itu merasa dirugikan. Kehormatan dan nama baik memiliki pengertian yang berbeda, tetapi keduanya tidak dapat dipisahkan satu dengan yang lain, karena menyerang kehormatan akan berakibat kehormatan dan nama baiknya tercemar, demikian juga menyerang nama baik akan berakibat nama baik dan kehormatan seseorang dapat tercemar. Oleh sebab itu, menyerang salah satu diantara kehormatan atau nama baik sudah cukup dijadikan alasan untuk menuduh seseorang telah melakukan penghinaan.

\section{E. Tinjauan Umum Media Sosial}

Media sosial adalah sebuah media online, dengan para penggunanya bisa dengan mudah berpartisipasi, berbagi dan menciptakan isi meliputi blog, jejaring sosial, wiki, forum dan dunia virtual. Blog, jejaring sosial dan Wiki merupakan bentuk media sosial yang paling umum digunakan oleh masyarakat di seluruh dunia. Saat teknologi internet dan mobile phone makin maju maka media sosial pun ikut tumbuh dengan pesat. Kini untuk mengakses instagram misalnya, bisa dilakukan dimana saja dan kapan saja hanya dengan menggunakan sebuah mobile phone. Demikian cepatnya orang bisa mengakes media sosial mengakibatkan terjadinya fenomena besar terhdap arus informasi tidak hanya di negara-negara maju, tetapi juga di Indonesia. Karena kecepatannya media sosial juga mulai tampak menggantikan peranan media massa konvensional dalam menyebarkan berita-berita. 


\section{METODE PENELITIAN}

Metode penelitian pada penelitian ini adalah kualitatif yaitu menjelaskan dengan kata-kata berupa narasi dengan membeberkan data yang ditemukan selama penelitian baik diperpustakaan, pengamatan dan wawancara. Lokasi penelitian di kota Samarinda, Tepatnya pada Kantor Kepolisian Resort Kota Samarinda. Populasi penelitian adalah Reserse Kriminal Kepolisian Kota Samarinda berjumlah 10 buah. Yang menjadi sampel yaitu sebanyak $25 \%$.

\section{IV.PEMBAHASAN}

Tindak Pidana Pencemaran Nama Baik melalui Media Elektronik yang diatur dalam Pasal 27 ayat (3) Undang-Undang Nomor 19 Tahun 2016 tentang perubahan atas Undang-Undang Nomor 11 Tahun 2008 tentang Informasi dan Transaksi Elektronik tidak menjelaskan secara rinci mengenai unsur "muatan Penghinaan dan/atau Pencemaran Nama Baik" sehingga pengertiannya bersifat subyektif. Maksudnya perasaan terserangnya nama baik seseorang hanya ada pada korban. Selain itu, dalam pasal tersebut juga terdapat unsur "Tanpa Hak" dimana pada unsur tersebut melekat unsur melawan hukum yang harus dibuktikan. Unsur ini mengindikasikan adanya hak yang diberikan pada pelaku Tindak Pidana Pencemaran Nama Baik melalui Media Elektronik. Namun, UndangUndangn Informasi Dan Transaksi Elektroniksendiri tidak memberi penjelasan secara rinci mengenai unsur tersebut. Yang menjadi permasalahan adalah pertama, apasajakah kriteria yang dapat dikualifikasikan sebagai tindak pidana pencemaran nama baik melalui media elektronik. kemudian permasalahan yang kedua adalah apakah dalam Pasal 27 ayat (3) Undang-Undang Nomor 19 Tahun 2016 tentang perubahan atas Undang-Undang Nomor 11 Tahun 2008 tentang Informasi dan Transaksi Elektronik terdapat unsur melawan hukum.

Hasil penelitian yang dilakukan oleh penulis langsung melalui wawancara dengan pihak Reskrim Polresta Samarinda Bapak Kompol Damus Asa, S.H, Slk mengatakan bahwa, tindak pidana pencemaran nama baik sekarang ini sering marak terjadi, disebebakan ketidaktepatan guna dalam pemanfaatan media sosial, contohnya seorang pria baru-baru ini saja melakukan tindak pidana pencemaran nama baik oleh seorang wanita melalui akun Instagramnya, dengan menyebut salah satu korban sebagai wanita Murahan, dan penegakan hukum yang langsung dilakukan oleh pihak kepolisian terhadap pelaku yaitu Ancaman pidana bagi orang yang melanggar Pasal 27 ayat (3) Undang-Undang Infomasi dan Transaksi Elektronik ini diatur dalam Pasal 45 ayat (3) UU 19/2016, yang berbunyi 
"Setiap Orang yang dengan sengaja dan tanpa hak mendistribusikan dan/atau mentransmisikan dan/atau membuat dapat diaksesnya Informasi Elektronik dan/atau Dokumen Elektronik yang memiliki muatan penghinaan dan/atau pencemaran nama baik sebagaimana dimaksud dalam Pasal 27 ayat (3) dipidana dengan pidana penjara paling lama 4 (empat) tahun dan/atau denda paling banyak Rp750.000.000,00 (tujuh ratus lima puluh juta rupiah)."

Upaya penanggulangan cybercrime oleh aparat kepolisian terdapat beberapa kendala yang menghambat upaya penanggulangan cybercrime, penulis kemudian memaparkannya berdasarkan hasil wawancara dan penelusuran referensi, bahwa penindakan kasus cybercrime sering mengalami hambatan terutama dalam penangkapan tersangka dan penyitaan barang bukti. Dalam penangkapan tersangka sering kali kita tidak dapat menentukan secara pasti siapa pelakunya karena mereka melakukannya cukup melalui komputer yang dapat dilakukan dimana saja tanpa ada yang mengetahuinya sehingga tidak ada saksi yang mengetahui secara langsung.

Hasil pelacakan paling jauh hanya dapat menemukan IP Address dari pelaku dan komputer yang digunakan. Hal itu akan semakin sulit apabila menggunakan warnet sebab saat ini masih jarang sekali warnet yang melakukan registrasi terhadap pengguna jasa mereka sehingga kita tidak dapat mengetahui siapa yang menggunakan komputer tersebut pada saat terjadi tindak pidana. Penyitaan barang bukti banyak menemui permasalahan karena biasanya pelapor sangat lambat dalam melakukan pelaporan, hal tersebut membuat data serangan di log server sudah dihapus biasanya terjadi pada kasus deface, sehingga penyidik menemui kesulitan dalam mencari log statistik yang terdapat di dalam server sebab biasanya secara otomatis server menghapus log yang ada untuk mengurangi beban server. Hal ini membuat penyidik tidak menemukan data yang dibutuhkan untuk dijadikan barang bukti sedangkan data log statistik merupakan salah satu bukti vital dalam kasus hacking untuk menentukan arah datangnya serangan.

\section{PENUTUP}

\section{A. Kesimpulan}

1. Tindak Pidana Pencemaran Nama Baik melalui Media Elektronik yang diatur dalam Pasal 27 ayat (3) Undang-Undang Nomor 19 Tahun 2016 tentang perubahan atas Undang-Undang Nomor 11 Tahun 2008 tentang Informasi dan Transaksi Elektronik tidak menjelaskan secara rinci mengenai unsur "muatan Penghinaan dan/atau Pencemaran Nama Baik" sehingga pengertiannya bersifat subyektif. Perbuatan pelaku 
tersebut merupakan pelanggaran terhadap ketentuan Pasal 27 ayat (3) Undang Undang nomor 19 tahun 2016 tentang perubahan atas Undang Undang nomor 11 Tahun 2008 tentang Informasi dan Transaksi Elektronik akan dijerat dengan Pasal 45 Ayat (1) Undang-Undang Nomor 19 Tahun 2016 Perubahan Atas Undang-Undang Nomor 11 Tahun 2008 yang menyebutkan: Setiap Orang yang memenuhi unsur sebagaimana dimaksud dalam Pasal 27 ayat (1), ayat (2), ayat (3), atau ayat (4) dipidana dengan pidana penjara paling lama 4 (enam) tahun dan/atau denda paling banyak Rp750.000.000,00 (Tujuh Ratus Lima Puluh Juta Rupiah). Dalam proses penyidikannya harus melibatkan saksi ahli bahasa untuk mengetahui apakah konteks bahasa yang digunakan oleh pelaku adalah tindak pidana atau bukan.

2. Penanganan perkara yang dilakukan oleh Penyidik Polresta Samarinda dalam proses penyidikan tidak selalu berjalan dengan lancar, beberapa kendala-kendala atau hambatan yang harus dihadapi dalam mengupayakan penegakan hukum terhadap pelaku tindak pidana Informasi Transaksi elektronik, khususnya adanya dugaan tindak pidana Informasi Transaksi Elektronik yang berunsurkan penghinaan dan atau pencemaran nama baik melalui media online. Hambatan maupun kendala yang dihadapi langsung oleh penyidik Polresta Samarinda, dalam pelaksanaan penegakan hukum terhadap adanya dugaan tindak pidana Informasi Trassaksi Elektronik yang berunsurkan penghinaan dan atau pencemaran nama baik melalui medi online, yaitu dari segi Personil atau Penyidik; Sarana Prasarana; dan Proses penanganan perkara .

\section{B. Saran-Saran}

1. Penegakan hukum khususnya bagi pelaku pencurian dengan kekerasan, diproses sesuai Seyogyanya penegak hukum agar setiap pelaku tindak pidana pencemaran nama baik ditindak dengan adil dan tegas sehingga penjatuhan sanksinya sepadan dan mengembalikan nama baik seperti semula. Walaupun setiap warga Negara memiliki hak dan kebebasan dalam berpendapat, namun sebaiknya masayarakat pada umumnya lebih berhati-hati dalam menggunakan media sosial dan tidak menyalahgunakannya untuk kejahatan

2. Untuk pemerintah kiranya memberikan dukungan dalam hal anggaran fasilitas terhadap teknologi yang digunakan oleh kepolisian, agar memudahkan penegakan hukum melalui penyidikan berupa perangkat teknologi yang lebih modern untuk meretas ppelaku pengguna pencemaran nama baik melalui media sosial, agar hukum yang berlaku bisa dapat di implementasikan dengan baik. 


\section{DAFTAR PUSTAKA}

Evra Willya. dkk, 2018, Senarai Penelitian Islam Kontemporer Tinjauan Multikultural, Deepublish, Yogyakarta

Suprawoto, 2018, Perkembangan Dan Praktik Di Indonesia, Prenadamedia Group, Jakarta

Leden Marpaung, 1991, Unsur- Unsur Perbuatan Yang Dapat Dihukum (Delik), Sinar Grafika, Jakarta),

Dellyana,Shant.2004, ,Konsep Penegakan Hukum, Liberty, Yogyakarta:

Undang-Undang Dasar Negara Republik Indonesia Tahun 1945.

Kitab Undang-undang Hukum Pidana (KUHP)

Kitab Undang-undang Hukum Acara Pidana (KUHAP)

Undang - Undang Nomor 2 Tahun 2002 Tentang Kepolisian Negara Republik Indonesia

Undang-Undang Republik Indonesia Nomor 19 Tahun 2016 Tentang Perubahan Atas Undang-Undang Nomor 11 Tahun 2008 Tentang Informasi Dan Transaksi Elektronik 